\title{
Basal ice temperatures during late Weichselian deglaciation: comparison of landform assemblages in west-central Sweden
}

\author{
INGMAR BORGSTRÖM \\ Department of Physical Geography, Stockholm University, S-106 91 Stockholm, Sweden
}

\begin{abstract}
The mountainous area of west-central Sweden has a varied glacial morphology and three unique landform assemblages appear to mark areas of different basal thermal conditions during the decay of late Weichselian ice. A glacial geomorphological map was constructed through interpretation of aerial photographs at a scale 1:60 000. The relative abundance of landforms interpreted to indicate a frozen bed, a thawed bed, and late- frozen to thawed-bed conditions were used for a first-order reconstruction of the basal temperature pattern of the decaying ice sheet. The features used to outline areas with different temperature regimes during deglaciation are glacial scouring, flutings, eskers, meltwater channels, boulder blankets, Rogen moraines, relict surfaces and thermoerosion features.

In the northern part of the area, as well as along most of the water divide to the Atlantic Ocean, the ice was warm-based during deglaciation. Glacially scoured bedrock, fluting/ drumlinization, subglacial eskers and extensive glacial lake sediments characterize the area. In the high mountain area, lateral meltwater channels are short and curve downslope to form chutes or eskers. The basal ice conditions changed from frozen- to thawedbed in a late stage of the late Weichselian cycle in most of the southern part of the area, shown by the Rogen moraines on both sides of the ice divide. However, substantial areas in the eastern and southern low mountains had frozen-bed conditions during the complete late Weichselian. In the high mountains in the north, only the summits were frozen.
\end{abstract}

\section{INTRODUCTION}

Knowledge about basal temperatures in former ice sheets is of vital importance for thermodynamic ice-sheet modelling (e.g. Hughes, 1981; Huybrechts and T'siobbel, 1997). The last 10-15 years have revealed abundant new data regarding the influence of ice temperatures on landforming processes (Dyke, 1993; Glasser, 1995). An overview is given by Kleman (1994). Mapping of landforms is the geographer's contribution to increased knowledge about the spatial distribution of basal thermal conditions in palaeo ice sheets. This is the aim of the present study, which describes basal temperature patterns inferred from landform assemblages laid down by the decaying ice sheet in west-central Sweden.

The area is $18000 \mathrm{~km}^{2}$ and constitutes the southernmost part of the mountain range in Sweden (Fig. 1). The area is drained by valleys that trend northwest to southeast. The valleys form distinct water gaps between the low mountains in the southeast and, locally, relief here exceeds $700 \mathrm{~m}$.

The high mountain area in the north constitutes the heart of the investigated area. This area contains four clearly delimited high mountain massifs: Sylarna-Helags, Skarsfjället, Snasahögarna and Bunnerfjällen-Härjångsfjällen. In the west, Sylarna-Helags rises from the extensive upland plateau, Helagsplatån. This massif is characterized by a great number of glacial cirques cut into the otherwise smoothly domedshaped summits. The gross morphology of Lunndörrsfjällen is, to a great extent, influenced by distinct trough valleys, their orientation being determined by dolerite dykes in sandstone.

The topography in the central part of the study area is composed mainly of horizontal or gently inclined high plateaux or weakly vaulted ridges.

The highest relief in the area, more than 1000 meters, is found adjacent to the Ottfjället-Åreskutan mountain block, which is located between the Annsjön basin and the lowland terrain around lake Kallsjön The area provides good opportunities for basal thermal studies: (1) During the Last Glacial Maximum (LGM), when the ice divide was located east and south of the area, large ice streams drained ice through the area towards the Atlantic Ocean (Lundqvist, 1969a; Borgström, 1989; Kleman and others, 1997). (2) During deglaciation the ice divide was located over the southeastern part of the area. (3) The gross morphology is varied, with high mountains and trough valleys, as well as low mountains and intervening high plateaux.

\section{DEGLACIATION}

The mapping of the glacial geomorphology was made with the aid of colour infrared aerial photographs, at a scale 1:60 000 .

\section{Reconstructing deglaciation}

The deglaciation was reconstructed using mapped lateral meltwater channels and ice-dammed lake formations. Only 


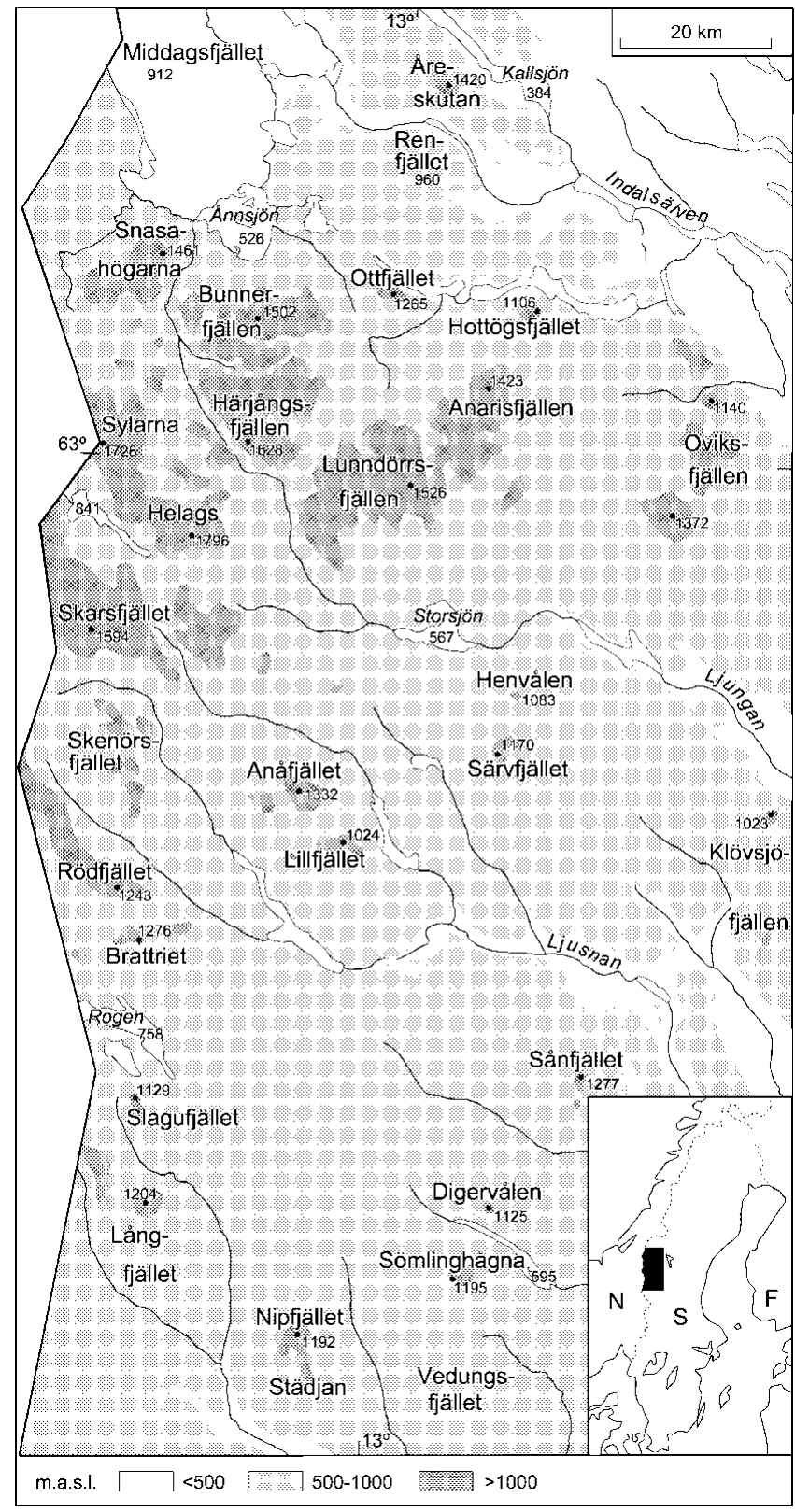

Fig. 1. Topography and location map. $(\mathcal{N}=$ Norway, $S=$ Sweden, $F=$ Finland.)
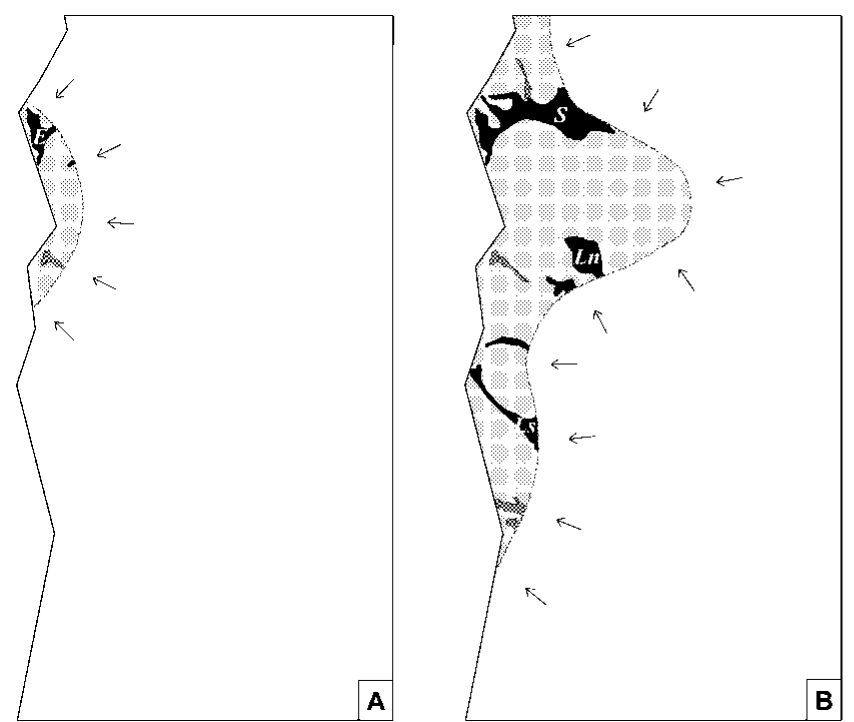

landforms forming part of a consistent deglaciation meltwater system were used in the reconstruction. Landforms that are cut by meltwater channels or overridden by flutings were excluded. A comprehensive description of the method is given in Borgström (1989) and Kleman and Borgström (1996).

\section{The decaying late Weichselian ice sheet}

Former studies of the deglaciation of the area have been mainly conducted by Frödin, Mannerfelt and Lundqvist. Frödin (1913) studied the large valleys and the glacial lakes, while Mannerfelt (1945) focused on meltwater traces and moraines in the mountains. Lundqvist (1973) gave a more complete picture of the deglaciation based on the mapping of surficial deposits (Lundqvist, 1969a) and clay-varve chronology (Lundqvist, 1964). The deglaciation pattern shown in Figure 2 is a summary from Borgström (1989) and is in good agreement with previous works on deglaciation.

The general ice-margin retreat was from west to east. During the deglaciation, ice was flowing into the area from two dispersal centres: one in the northeast outside the study area and one in the southeast, continuously moving into the area. The retreat resulted in the damming of large glacial lakes, between the decaying ice and the mountains to the west. The water divide is situated approximately on the Swedish-Norwegian border in the northern part of the area. The glacial lake traces, especially deltas, shorelines and spillway channels, are quite common in the western and central parts. Most lakes were connected through drainage routes, a factor of vital importance for the reconstruction of the deglaciation. Three main lake complexes existed in the area (Fig. 2). Each of these passed through several stages with successively lower lake levels.

At a late stage in the deglaciation, an ice divide was located over the southern part of the area (Fig. 2). Meltwater channels here show drainage to the south, southeast and even southwest. Glacial lineations and Rogen moraines clearly show that the ice divide migrated into the area from the southeast. It is uncertain if the divide migrated further to the northwest prior to the final position in Figure 2c. Such a position is indicated by the fact that some of the Rogen
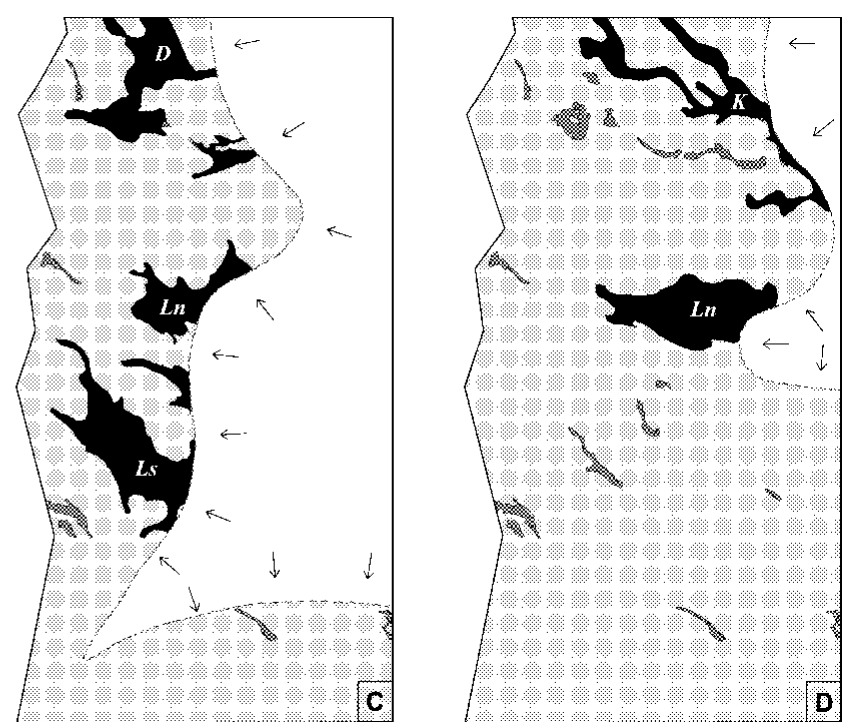

Fig. 2. The deglaciation of the area. The general ice margin retreat was to the east, with large glacial lakes dammed to the waterdivide in the west and ice flowing into the area from ice centres in the northeast and southeast. ( $E=$ Ena-issjön, $S=$ Storli-issjön, Ln = Ljungan-issjön, Ls = Ljusnan-issjön, $D=$ Duved-issjön, $K=$ Kall-issjön.) (From Borgstöm, 1989). 
moraines in the southwest do not seem to fit with the last ice divide.

\section{BASAL THERMAL REGIMES}

\section{Inferring basal regime from landforms}

Many papers on glaciology and glacial geomorphology focus on basal thermal regime and its importance for understanding landform genesis. However, the technique of inferring thermal regime from given landforms is not often described. Examples on this kind of work are Sugden (1977), Dyke (1993), Kleman and Borgström (1994) and Sollid and Sørbel (1994).

The following sections give the arguments for using certain landforms as indicators of ice temperatures.

\section{Landforms indicating warm-based ice}

Glacial scouring is generally accepted as an indicator of warmbased ice (cf. Drewry, 1986). Sugden (1978) described this type of landscape, which is similar to the knock-and-lochain morphology introduced already by Linton (1963). Basal sliding, with plucking and abrasion under a thawed bed, is generally accepted as a process responsible for creating this terrain (e.g. Andrews and others, 1985). In this study, when the individual landforms, as roche moutonées, correlate with ice movements inferred by the deglaciation pattern, the features are presumed to indicate warm-based ice during the late Weichselian deglaciation.

The exact origin of drumlins and fluting is much debated. Both accretion and erosion theories exist (Drewry, 1986), as well as the theory of deforming beds (Boulton, 1987). All theories seem to presume wet-bed conditions. Some cases have been reported where flutes have been found frozen into the ice at the glacier snout (Gordon and others, 1992), which could imply a cold-based origin. However, it is also possible that the flutes were frozen on to the sole in a phase with thinning ice (Benn and Evans, 1998). It is assumed here that streamlining of glacier beds is only possible under a thawed glacier bed.

Subglacial eskers and meltwater channels also require a thawed water-penetrable bed. Many eskers in the northern and western part of the area are located in former glacial lake basins, which suggests they are of subglacial origin. Some of the smaller eskers on the low mountain plateaux may have been formed supraglacially and therefore cannot be used as temperature indicators.

Short meltwater channels that quickly curve downslope to form subglacial chutes can also be used to demarcate warmbased conditions. This type of channel cannot form when the ice is cold because it is then non-penetrable for meltwater drainage.

\section{Landforms indicating cold-based ice}

Surfaces with intensely weathered bedrock and well-developed patterned ground occur on many mountain summits. Lateral meltwater channels cut such surfaces at several localities, which implies that the weathered surfaces are of pre-late Weichselian age. They can thus be used as indicators of cold-based ice during deglaciation. Where the bedrock is glacially stripped of boulders as on Åreskutan, in some patches of Lunndörrsfjällen (Fig. 7) and Nipfjället, there are no signs of Holocene frost shattering. It is also supported by the fact that the patterned ground is often abruptly replaced by a homogeneous surface, with no sign of periglacial patterns. Although frost-shattered bedrock and patterned ground generally occur on mountain summits, the local appearance is one of an irregular patchiness. The distribution can not be explained by differences in topography, bedrock geology or local climate, but most likely reflects differential glacial erosion or accumulation due to a different basal regime. Sometimes the relict surfaces have distinct borders carrying erosion scarps or shear moraines against surrounding terrain that was fluted and eroded during the late Weichselian (Kleman and Borgström, 1994).

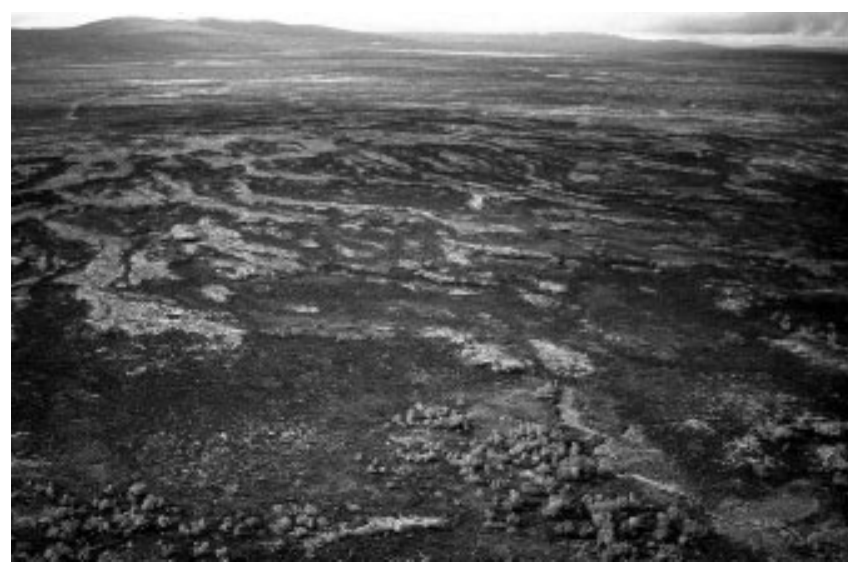

Fig. 3. Thermoerosion landforms on Vedungsfjället. The slopes are aligned with thermoerosion ridges and hummocks. The summits of these features are remnants of the pre-late Weichselian surface. (Width in centre of photo is $500 \mathrm{~m}$.)

Thermoerosion features, mostly scarps and ridges (Fig. 3), are found on slopes in close connection to relict surfaces in the area. Similar features have been documented in supraglacial environments (Paul, 1983) and have also been found in permafrost regions. Astakhov and Isayeva (1988) described the formation of "thermocirques" in Siberia, where the ground ice is supposed to be early Weichselian glacier ice. Lewkowicz (1992) described similar features from Canada. In both, the erosion is backwasting and initiated by running water. The thermoerosion features in the study area are always located on mountain or valley sides and often associated with flights of long meltwater channels that have drained the water that seemed to have initiated the backwasting. In at least one case, on the northern slopes of Anåfjällen, wave activity in a glacial lake initiated the thermoerosion. These landforms indicate a permafrost environment during deglaciation, and thus coldbased ice. This opinion was also put forward by Lagerbäck (1988).

Flights of long, consistent lateral meltwater channels reflect a cold ice surface. A cold ice surface is probably the only way to prevent water from penetrating down into the ice for long distances and during several melting seasons (Sollid and Sörbel, 1982, 1988; Dyke, 1993). A low crevasse frequency may also prevent surface water from draining into the ice, but this is unlikely to be the case for long distances in a mountainous area.

Glacial features related to earlier glacial stages may also indicate cold-based conditions. However, preservation of certain landforms such as large drumlins is also possible under thawedbed conditions (Lagerbäck, 1988; Clark, 1993; Kleman, 1994).

Landforms indicating a transition from cold-based to warm-based ice Kleman and Borgström $(1990,1994)$ described boulder blankets as boulder masses formed by the deposition of boulders, gla- 


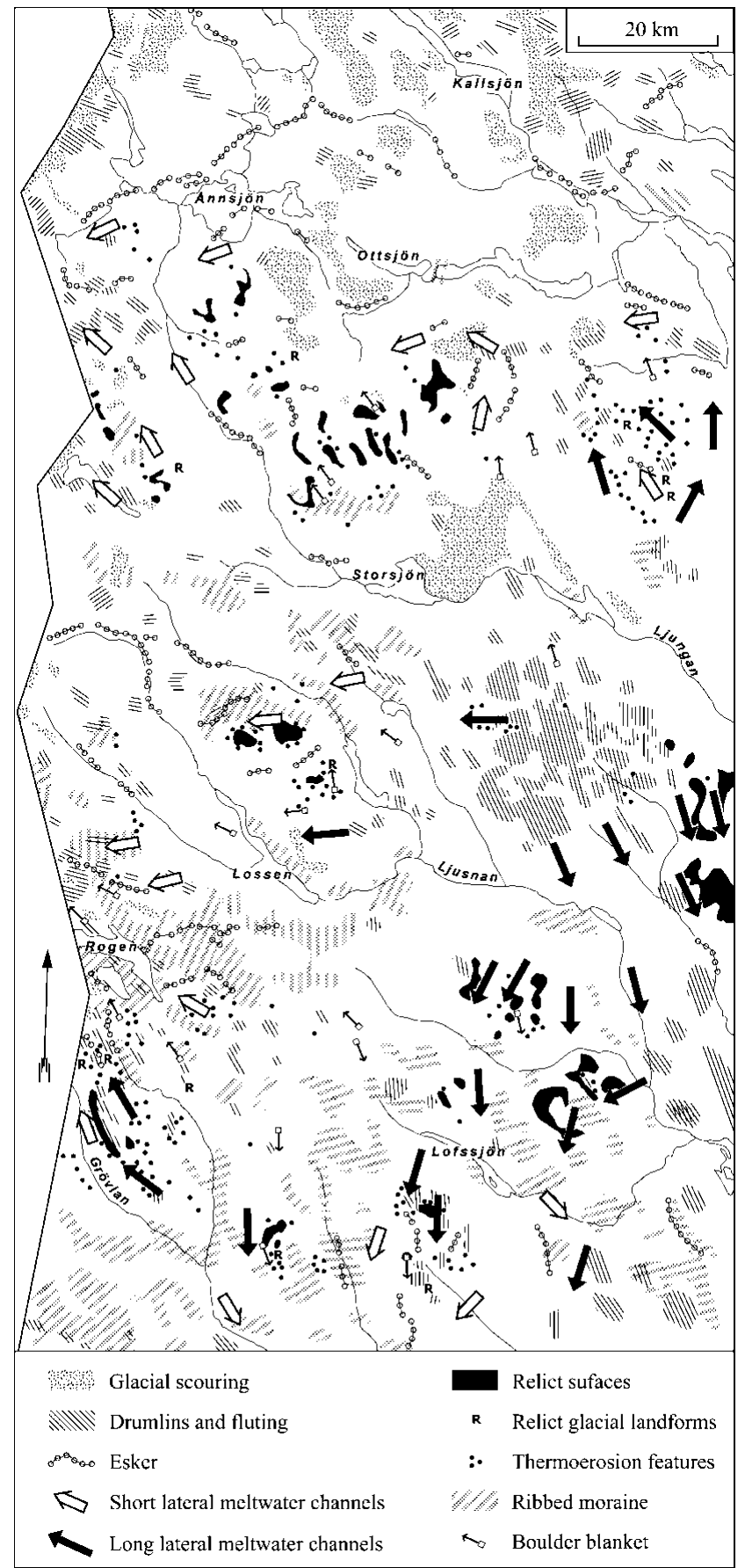

Fig. 4. Glacial geomorphology. The map is based on interpretation of aerial photographs at a scale of 1:60000.

cially transported over short distances. The source can often be related to scars in boulder fields or talus formations immediately up-ice. The direction of transportation usually corresponds with the last local ice-flow direction inferred from striations (Kleman, 1992). They are believed to form in a phase; the basal parts melt shortly before ice movement ceases during deglaciation. Thus, they most likely reflect a late-frozen to thawed-bed transition.

The formation of Rogen moraines (ribbed moraines) is discussed in numerous papers. A review is given by Hättestrand and Kleman (1999). Hättestrand's (1997) model is interesting since it accounts for morphological, as well as geographical and stratigraphical, criteria. It also gives a plausible explanation of the dynamics and interactions between the glacier bed and its substratum. The ridges are believed to have been formed by detachment of frozen drift when the pressure-melt-

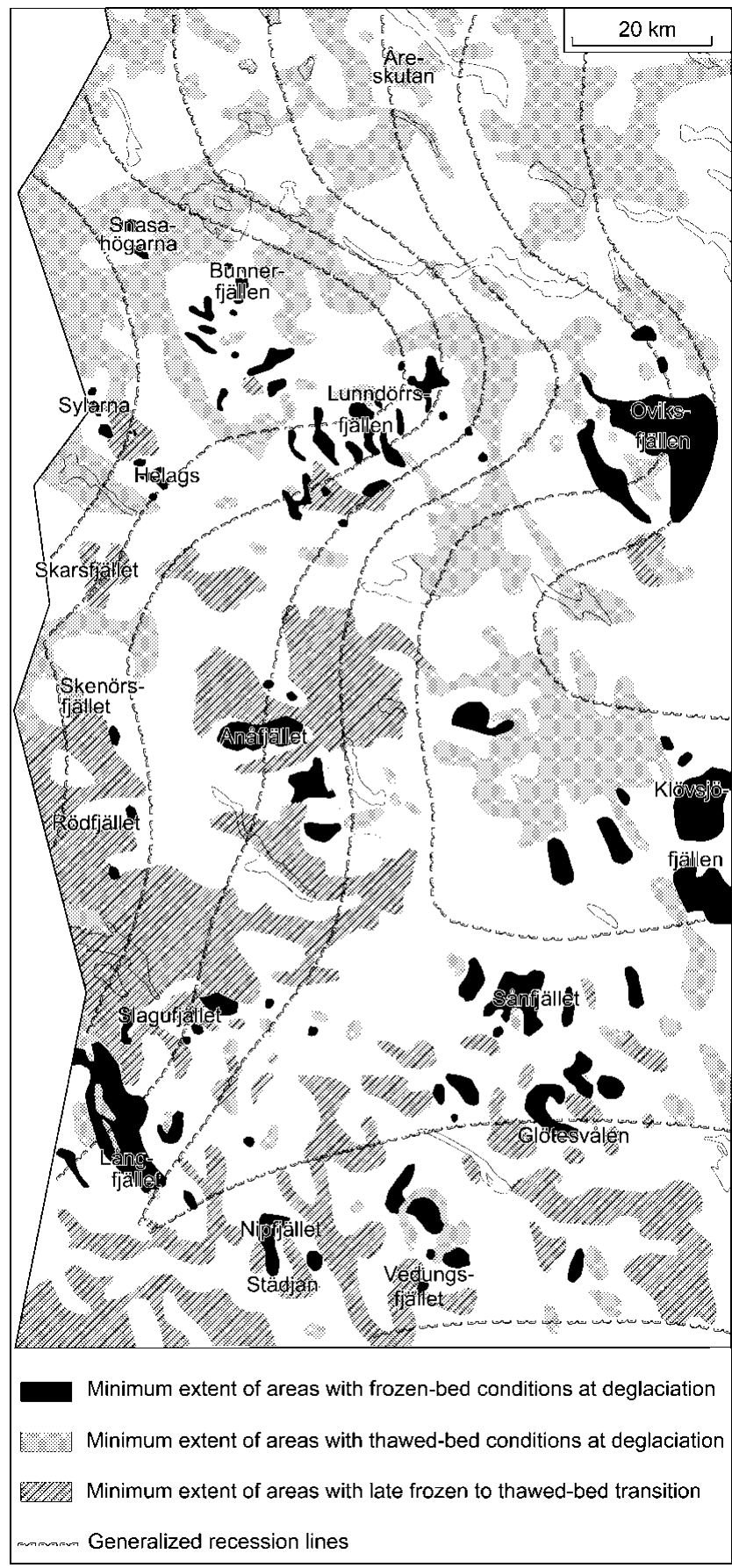

Fig. 5. Basal temperatures during deglaciation interpreted from glacial-geomorphology map in Figure 4. In the northern part, as well as along most of the water divide to the Atlantic Ocean, the ice was warm-based during deglaciation. Glacially scoured bedrock, fluting, large eskers and extensive glaciallake sediments characterize the area. In the high mountain area, lateral meltwater channels are short and bend downslope to form chutes or to be followed by subglacially engorged eskers. The basal ice melted in a late stage of the deglaciation in the southern part of the area, which is demarcated by the Rogen moraines on both sides of the ice divide. Large areas in the eastern and southern low mountains were cold-based during deglaciation. In the high mountains in the north, only the summits were cold-based.

ing isotherm ascended through the glacier bed. The bed may have been completely thawed before deglaciation, but the ridges were only slightly remoulded or drumlinized because of stagnating ice movement close to the ice divide. However, 
there is still a question of how close to deglaciation the moraines were formed. As was shown in previous studies of the area (cf. Lundqvist, 1969b; Borgström, 1989), many Rogen moraines were formed in high-relief topography without any sign of deviation from the overall flow direction in a fairly thick $(>1000 \mathrm{~m})$ ice sheet. This implies that at least some of the Rogen moraine areas thawed a considerable time before ice-free conditions.

\section{Summarizing assumptions}

Glacial scouring, glacial lineations, subglacial eskers and chutes are assumed to indicate warm-based conditions. When individual landforms fit into the deglaciation pattern inferred from coherent marginal meltwater traces, the landform assemblages are believed to demarcate areas that had warmbased conditions during the late Weichselian deglaciation.

It is assumed the ice was cold-based during deglaciation in areas where relict surfaces dominate on mountain summits, and where thermoerosion features and flights of long lateral meltwater channels dominate on mountain and valley slopes.

Rogen moraines and boulder blankets reflect a transition from cold-based to warm-based conditions in a late stage of the late Weichselian cycle.

\section{Basal thermal regimes during deglaciation}

The mapping of landforms is shown in Figure 4. Given uncertainties in the associations discussed above, it is hereby assumed that these are correct and justify the following theoretical exploration of thermal regimes during deglaciation. The interpretations are summarized in Figure 5.

\section{Thawed-bed conditions}

Thawed-bed conditions appear to have been the dominating thermal regime in the northern and northwestern part of the area. This is inferred from the widespread occurrence of glacially scoured terrain. Apart from the scoured bedrock, fluting, eskers and glacial-lake sediments characterize this area. A few large drumlins are also found here. The erosion seems to have been moderate, since stoss-and-lee topography, formed by earlier ice flow from the northwest, is still present in the scoured terrain.

The most extreme examples of glacial scouring are found along the Swedish-Norwegian border and across the Åreskutan-Ottfjället mountain ridge. There is almost no surficial material, except peat, in these areas. This is also true for the summit area of Åreskutan (1420 m a.s.l.), where the lack of unconsolidated sediment implies that no frost shattering occurred here during the Holocene.

The northern and northwestern areas also show numerous short channel flights. Sometimes the lateral channels curve downslope to form chutes (Fig. 6) and sometimes the channels are replaced by eskers. An illustrative example of the latter situation is the Dörrsjöarna valley in Oviksfjällen. The thawed-bed conditions here seem to be a consequence of the high flow rates of ice converging into the valley. Subglacial eskers are frequent in the north and northwest. The larger ones are situated in valleys, the Indalsälven valley esker in the north is the largest and longest, locally more than $40 \mathrm{~m}$ high. Large eskers also occur in the western parts of the Ljusnan valley. There is a strong connection between large eskers and the amount of glacial lake sediments. The sediments are most widespread in the Indalsälven valley, with a thickness sometimes reaching $10 \mathrm{~m}$ (Lundqvist, 1969a).

An extensive area of scouring is found in the Ljungan basin, northeast of Storsjön. Although many bedrock hills in this area reflect glacial plucking from the northwest, roche moutonées and crag-and-tail features clearly show that the last ice movement was from the southeast. This area is part of a narrow zone of glacial scouring and fluting that stretches to the southeast over the plateau east of Henvålen-Särvfjället. The last local ice divide was situated over this plateau, implying that the lineations were formed prior to the deglaciation when the ice divide was located further to the southeast, possibly during the LGM (Kleman and others, 1997).

A striking feature is the lack of eskers, as well as glaciallake sediments, in the eastern areas of glacial lakes Ljunganissjön and Ljusnan-issjön. This may be a result of low erosion rates, either due to cold-based ice or stagnant ice, near the ice divide. The scoured area northeast of Storsjön and the fluting field east of Särvfjället indicate the ice was warmbased in the Ljungan valley at an earlier stage. It seems unlikely the ice would refreeze in the valley to prevent production of eskers and glacial lake sediments. Hence, the short distance to the ice divide is a likely explanation.

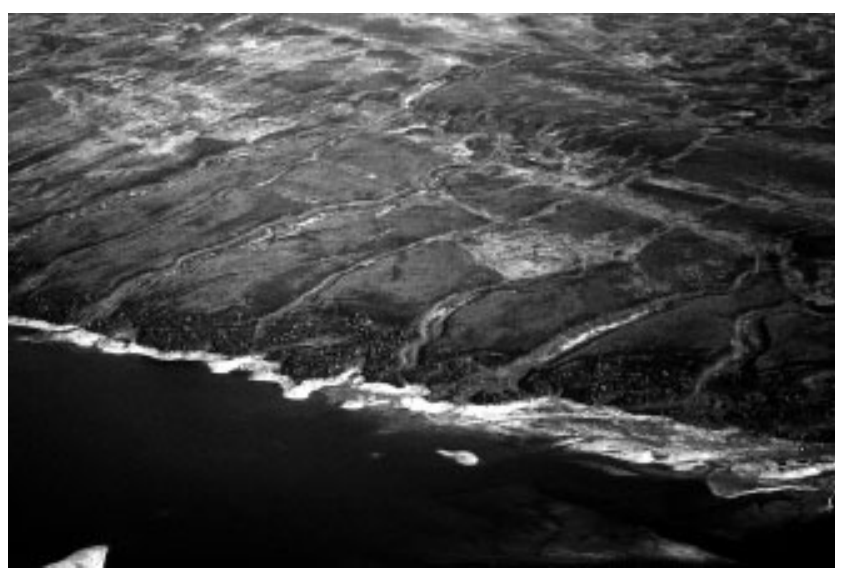

Fig. 6. Subglacial chutes in the Sylsjön valley. Short lateral meltwater channels and subglacial chutes indicate wet-bed ice. (Width in centre of photo is $1600 \mathrm{~m}$.)

\section{Frozen-bed conditions}

Frozen-bed conditions seem to have dominated in the low mountain terrain in the east, south and southwest. Boulder fields and patterned ground are almost invariably found here on topographic highs. The pre-late Weichselian origin of these surfaces is clearly demonstrated by lateral meltwater channels that are cut into boulder fields (cf. Klövsjöfjällen), boulder blankets that are drawn out from the boulder fields (cf. Sånfjället) and glacially eroded scarps in the patterned ground (cf. Häggingfjället, southwest of Sömlinghågna) (Kleman and Borgström, 1994).

Flights with long lateral meltwater channels also occur in the southern and eastern low mountains. They are often found high up on the summits, but can sometimes also reach all the way down to local valley bottoms, as in Klövsjöfjällen. They often completely surround the mountains. However, many channel flights have been more or less destroyed by thermoerosion processes, leaving only short remnants of individual channels intact.

Relict glacial landforms seem to occur on topographic highs in most of the area. They are especially frequent in Oviksfjällen, on Städjan-Nipfjället and on Långfjället. A large terminal moraine is situated on the mountain ridge 


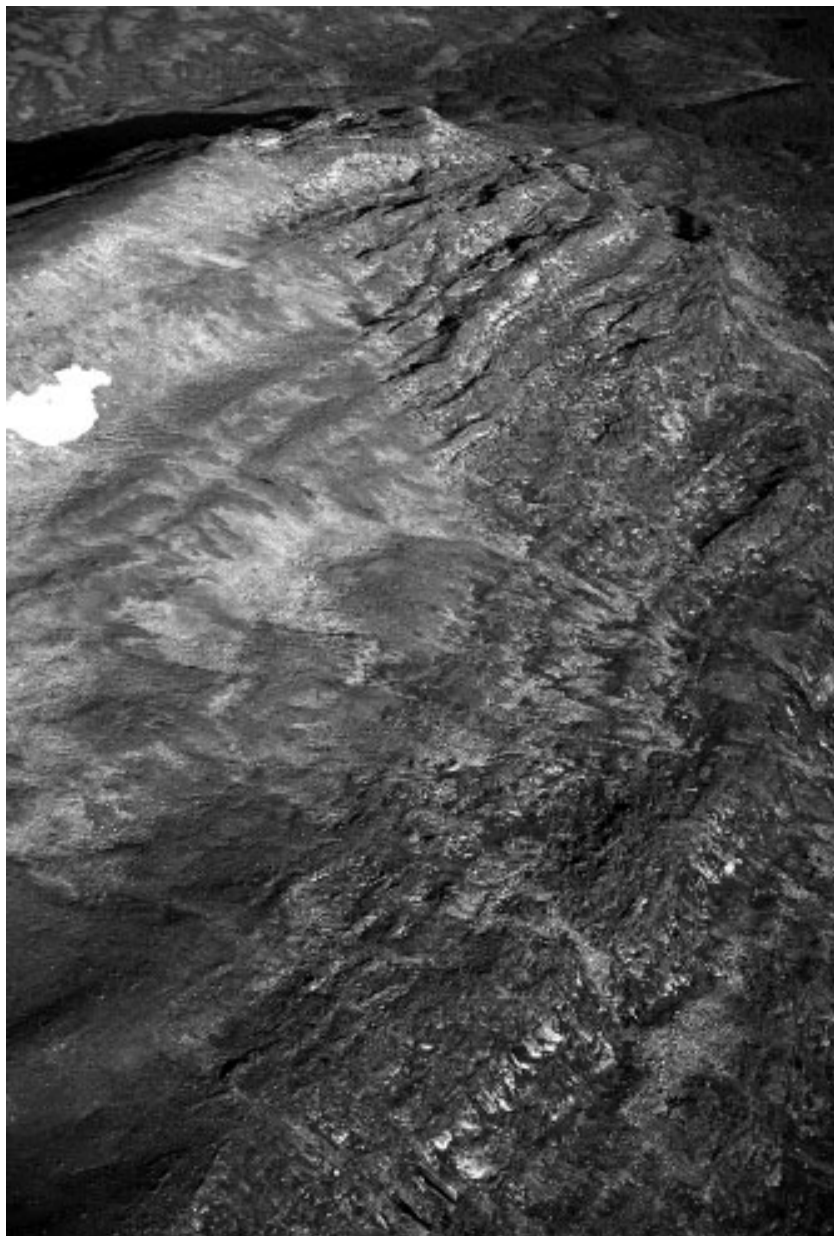

Fig. 7. Boulder field on a summit in Lunndörrsfjällen, partially stripped by late Weichselian ice flow. (Photo: A. Philip). (Width in centre of photo is $400 \mathrm{~m}$.)

between Nipfjället and Städjan. Fossil ice-wedge polygons can be seen on top of the ridge. A similar ridge is located on Långfjället, near the border with Norway. Both moraines contain kettle holes. Kleman (1992) mapped similar moraines in the northern part of Sweden, where they were interpreted to represent a temporary halt in the recession of an older west-centred ice sheet.

Relict surfaces also occur in the northern mountains. The surfaces here are often restricted to the high mountain peaks, as in Sylarna and Helags, or to rather narrow remnants of dissected high mountain plateaux, as in Lunndörrsfjällen and Bunnerfjällen. Several localities with boulder blankets in Lunndörrsfjällen show the glacial plucking of boulder fields (Fig. 7).

\section{Frozen- to thawed-bed transition}

Following the hypothesis by Hättestrand (1997), that Rogen moraines occur where the bed is recently thawed, there is an area mainly in the south and southwest on both sides of the ice divide where such an evolution occurred in valleys and on plateaux. In general, Rogen moraine areas and glacially scoured areas exclude each other. However, in some areas the two types occur together: around lake Rogen, most of the low mountain hills are scoured and even heavily plucked in the westernmost parts.

Boulder blankets are often found associated with relict surfaces. They form drawn-out tails from frost-shattered bedrock on Häggingfjället (southwest of Sömlinghågna),
Sånfjället, Slagufjället and in Lunndörrsfjällen, and from talus formations on Lillfjället and Nipfjället. They show that the frozen patches all over the area probably were larger prior to deglaciation and that the erosion stopped because of stagnating ice movement.

Both eskers and fluting in the southeastern area indicate that the landforming processes continued after the bed had thawed, but the alteration of the terrain was small. Eskers on the plateaux and in the mountains are generally small and short, rarely more than $10 \mathrm{~m}$ high, and the fluting is faint.

\section{DISGUSSION}

The retreat pattern shown in Figure 2 is in broad agreement with reconstructions made by most glacial geologists working in the area. Some uncertainties exist concerning the southernmost parts, southeast of the last ice divide, since this region is expected to contain landform records from earlier glacial phases that were preserved in cold-based ice during the lateWeichselian. The lack of glacial-lake traces in this area makes the tracing of the retreat pattern less accurate than further north.

The interpretation of thermal regimes (Fig. 5) is based on a number of assumptions regarding the genesis of individual landforms. However, the basal thermal conditions have been inferred from entire landform assemblages, which reduces the uncertainities. For instance, there is a very low probability that an area with glacial scouring, fluting and subglacial chutes was cold-based during deglaciation. It follows that areas that are outlined with few landforms involve greater uncertainty. The most obvious is the transitional conditions inferred by Rogen moraines and boulder blankets. The latter are rather rare features and, therefore, most of the identification of the transition types rely on the distribution of Rogen moraines.

The relict surfaces are probably the most reliable evidence for frozen beds on many mountain summits in the area and they presumably indicate cold-based ice during the complete late Weichselian stage. Their occurrence on topographic highs is in agreement with the predictions of most ice-sheet models. In the high mountain plateaux of Lunndörrsfjällen and Bunnerfjällen, the relict surfaces occur in positions where no erosion is to be expected, since ice flow is channelled in trough valleys. The Lunndörrsfjällen- Bunnerfjällen area can be classified as a "landscape of selective linear erosion" (Sugden, 1978).

The erosion of relict surfaces in many cases seems to reflect basal conditions inherited from earlier phases. The partially stripped boulder field on a summit in Lunndörrsfjällen (Fig. 7) is a good illustration of this situation, where the warm-based ice must have been generated when the ice was flowing in one of the up-ice trough valleys or on the plateau further to the southeast.

If the interpretation of basal regimes is correct, the northern parts of the area were warm-based at least during the deglaciation, possibly even at the LGM, while extensive areas in the southern and southwestern parts were coldbased during most of the late Weichselian. An explanation for this may be that ice flow was drained over the low mountains at the water divide west of Ånnsjön, when the ice divide was situated east of the mountain range. It is also possible that the shorter distance to the ice divide in the southeast is an important factor in the thermal distribution pattern. 


\section{GONCLUSIONS}

With the assumptions that: (a) glacial scouring, glacial lineations, subglacial eskers and chutes indicate warm-based conditions; (b) the ice was cold-based in areas where relict surfaces dominate on mountain summits and where thermoerosion features and flights of long, consistent lateral meltwater channels dominate on mountain and valley slopes; and that (c) Rogen moraines and boulder blankets reflect a transition from cold-based to warm-based conditions in a late stage of the late Weichselian cycle, it is concluded that:

(1) the ice was warm-based during deglaciation in the northern and northwestern part of the study area;

(2) a swarm of lineations and glacially scoured bedrock demarcates a thawed-bed zone from the region south of Klövsjöfjällen in a north-northwesterly direction into the northern parts of the area. The zone crosses the last local ice divide and likely represents a pre-deglaciation ice stream, possibly active during the late Weichselian maximum;

(3) most of the valleys and plateaux in the southwestern part of the area changed from frozen to thawed-bed conditions at a late stage of the late Weichselian; and

(4) substantial areas in the eastern and southern low mountains had frozen-bed conditions during deglaciation. In the high mountains in the north, only the summits were cold-based.

\section{ACKNOWLEDGEMENT}

I want to thankJ. Kleman and an unknown referee for constructive comments on the manuscript.

\section{REFERENCES}

Andrews, J. T., J. A. Stravers and G. H. Miller. 1985. Patterns of glacial erosion and deposition around Cumberland Sound, Frobisher Bay and Hudson Strait, and the location of ice streams in the eastern Canadian Arctic. In Woldenburg, M. J., ed. Models in geomorphology. Vol. 14. Winchester, MA, Allen and Unwin, 82-117.

Astakhov, V. I. and L. L. Isayeva. 1988. The "ice hill": an example of "retarded deglaciation" in Siberia. Quat. Sci. Rev., 7(1), 29-40.

Benn, D. I. and D. J. A. Evans. 1998. Glaciers and glaciation. London, Arnold.

Borgström, I. 1989. Terrängformerna och den glaciala utvecklingen i de södra fjällen. Stockholms Univ. Geogr. Inst. Medd. 234.

Boulton, G. S. 1987. A theory of drumlin formation by subglacial sediment deformation. In Menzies, J. and J. Rose, eds. Drumlin Symposium. Rotterdam, A.A. Balkema, 25-80.

Clark, C. D. 1993. Mega-scale glacial lineations and cross-cutting ice-flow landforms. Earth Surf. Processes Landforms, 18(1), 1-29.

Drewry, D. 1986. Glacial geologic processes. London, Edward Arnold.

Dyke, A. S. 1993. Landscapes of cold-centred Late Wisconsinan ice caps, Arctic Canada. Prog. Phys. Geogr., 17 (2), 223-247.

Frödin, G. 1913. Bidrag till västra Jämtlands senglaciala geologi. Sver. Geol.
Unders., Ser. C 251.

Glasser, N. F. 1995. Modelling the effect of topography on ice sheet erosion, Scotland. Geogr. Ann., 77A (1-2), 67-82.

Gordon, J. E., W. B. Whalley, A. F. Gellatly and D. M. Vere. 1992. The formation of glacial flutes: assessment of models with evidence from Lyngsdalen, north Norway. Quat. Sci. Rev., 11(7-8), 709-731.

Hättestrand, C. 1997. Ribbed moraines in Sweden - distribution pattern and paleoglaciological implications. Sediment. Geol., 111(1-4), 41-56.

Hättestrand, C. and J. Kleman. 1999. Ribbed moraine formation. Quat. Sci. Rev., 18(1), 43-61.

Hughes, T. J. 1981. Numerical reconstruction of paleo-ice sheets. In Denton, G. H. and T. J. Hughes, eds. The last great ice sheets. New York, etc., John Wiley and Sons, 221-261.

Huybrechts, P. and S. T'siobbel. 1997. A three-dimensional climate-icesheet model applied to the Last Glacial Maximum. Ann. Glaciol., 25, 333-339.

Kleman, J. 1992. The palimpsest glacial landscape in northwestern Sweden - Late Weichselian deglaciation landforms and traces of older west-centered ice sheets. Geogr. Ann., 74A(4), 305-325.

Kleman, J. 1994. Preservation of landforms under ice sheets and ice caps. Geomorphology, 9(1), 19-32.

Kleman, J. and I. Borgström. 1990. The boulder fields of Mt. Fulufjället, west-central Sweden - Late Weichselian boulder blankets and interstadial periglacial phenomena. Geogr. Ann., 72A(1), 63-78.

Kleman, J. and I. Borgström. 1994. Glacial land forms indicative of a partly frozen bed. f. Glaciol., 40(135), 255-264.

Kleman, J. and I. Borgström. 1996. Reconstruction of palaeo-ice sheets: the use of geomorphological data. Earth Surf. Processes Landforms, 21 (10), 893-909.

Kleman, J., C. Hättestrand, I. Borgström and A. Stroeven. 1997. Fennoscandian palaeoglaciology reconstructed using a glacial geological inversion model. f. Glaciol., 43(144), 283-299.

Lagerbäck, R. 1988. Periglacial phenomena in the wooded areas of northern Sweden - relicts from the Tärendö interstadial. Boreas, 17 (4), 487-499.

Lewkowicz, A. G. 1992. Factors influencing the distribution and initiation of active-layer detachment slides on Ellesmere Island, Arctic Canada. In Dixon, J. C. and A. D. Abrahams, eds. Periglacial geomorphology. Chichester, etc., John Wiley and Sons, 223-250.

Linton, D. L. 1963. The forms of glacial erosion. Inst. British Geogr. Trans. Pap. $33,1-28$.

Lundqvist, J. 1964. Preliminary results of geochronological investigations in Jämtland. Geol. Fören. Stockholm Förh., 86(2), 174-178.

Lundqvist, J. 1969a. Beskrivning till jordartskarta över Jämtlands län. Sver. Geol. Unders., Ser. Ca 45.

Lundqvist, J. 1969b. Problems of the so-called Rogen moraine. Sver. Geol. Unders., Ser. C 648.

Lundqvist, J. 1973. Isavsmältningens förlopp iJämtlands län. Sver. Geol. Unders., Ser. $C 681$.

Mannerfelt, C. M:son. 1945. Några glacialmorfologiska formelement och deras vittnebörd om inlandsisens avsmältningsmekanik i svensk och norsk fjällterräng. Geogr. Ann., 17(1-2), 1-239.

Paul, M. A. 1983. The supraglacial landsystem. In Eyles, N., ed. Glacial geology: an introduction for engineers and earth scientists. Oxford, Pergamon Press, 71-90.

Sollid, J. L. and L. Sørbel. 1982. Kort beskrivelse till glasialgeologisk kart over Midt-Norge 1: 500 000. Nor. Geogr. Tidsskr., 36(4), 225-232.

Sollid, J. L. and L. Sørbel. 1988. Influence of temperature conditions in formation of end moraines in Fennoscandia and Svalbard. Boreas, 17(4), 553-558.

Sollid, J. L. and L. Sørbel. 1994. Distribution of glacial landforms in southern Norway in relation to the thermal regime of the last continental ice sheet. Geogr. Ann., 76A(1-2), 25-35.

Sugden, D. E. 1977. Reconstruction of the morphology, dynamics and thermal characteristics of the Laurentide ice sheet at its maximum. Arct. Alp. Res., 9(1), 21-47.

Sugden, D. E. 1978. Glacial erosion by the Laurentide ice sheet. F. Glaciol., $\mathbf{2 0}(83), 367-391$. 